\title{
ANALISIS TEKNIS PENGARUH PENAMBANGAN BATU PADAS TERHADAP KERUSAKAN DAERAH ALIRAN SUNGAI OOS DI UBUD GIANYAR
}

\author{
I Wyn Suasira ${ }^{(1)}$, I Made Tapayasa ${ }^{(2)}$, \\ I Made Anom Santoiana ${ }^{(3)}$, I Gusti Lanang Made Parwita ${ }^{(4)}$ \\ ${ }^{1,2,3,4}$ Dosen Jurusan Teknik Sipil Politeknik negeri Bali, Kampus Politeknik Negeri Bali Bukit Jimbaran, \\ email:suasira@gmail.com
}

\begin{abstract}
ABSTRAK
Pada jaman dahulu pemakaian material batu padas di Bali pada umumnya terbatas hanya untuk bangunan suci dan untuk keperluan perumahan bangsawan/ keraton. Namun dengan perkembangan jaman seiring dengan berkembang pesatnya sektor kepariwisataan menyebabkan pemakaian batu padas semakin luas penggunaannya baik untuk kantor, sekolah, tempat bisnis maupun untuk akomodasi kepariwisataan. Kondisi ini membawa konsekwensi terhadap meningkatnya permintaan terhadap material batu padas dari waktu ke waktu. Kondisi lain lagi penambangan batu padas yang berlokasi di sepanjang alur daerah aliran sungai Oos diyakini memiliki kwalitas material terbaik di Bali dilihat dari tekstur, warna dan kekuatan materialnya. Permasalahan mulai timbul dimana permintaan batu padas yang meningkat tidak diikuti dengan penyediaan yang memadadi karena persediaan di alam cenderung tetap bahkan mulai berkurang. Kondisi yang ada saat ini menunjukkan bahwa kegiatan penambangan batu padas tersebut telah mulai menimbulkan kerusakan terhadap sungai. Dari penelitian pendahuluan yang dilakukan di Desa Lodtunduh Kecamatan Ubud Kabupaten Gianyar menunjukkan bahwa pengambilan batu padas mulai menunjukkan perubahan yang sangat besar terhadap lingkungan di sekitarnya dilihat dari jumlah material yang diambil, kedalaman penggalian, penurunan kalitas air, kebisingan suara serta berkurangnya kapasitas sungai. Kondisi ini membawa konsekwensi terhadap beberapa hal negatif seperti alur sungai yang mulai mengalami perubahan serta daerah sekitar aliran sungai yang tidak lagi memperhatikan aspek keamanan serta estetika lingkungan. Kwalitas air sungai yang menurun memberi dampak yang tidak bagus terhadap sungai serta terancamnya daerah tebing di sekitar sungai yang berpotensi longsor. Penelitian ini memakai metode deskriftif kwantitatif dan kwalitatif dengan hasil yang diharapkan berupa suatu pola kebijakan penataan Tukad Oos yang komprehensif dan inovatif sehingga kerusakan sungai dapat dicegah. Hasil akhir dari penelitian ini adalah adanya suatu pola kebijakan dalam penambangan batu padas di daerah aliran sungai Oos sehingga kerusakan yang lebih besar bias dihindari.
\end{abstract}

Kata Kunci: Sungai Oos, tambang batu padas, kerusakan sungai

\section{ABSTRACT}

In ancient times the use of rock material in Bali in general was limited only to the sacred buildings and for the purposes of royal or palace housing. However, the development of the era along with the rapidly growing tourism sector led to the use of stone more widely or offices, schools, business places and for tourism accommodation. This condition brings consequences to the increasing demand for rock material over time. Another condition of stone rock mining located along the flow of the Oos river basin is believed to have the best material quality in Bali in terms of texture, color and material strength. Problems begin to arise where increasing demand for rocks is not accompanied by an adequate supply because the inventories in nature tend to remain even begin to decrease. Current conditions indicate that the rock mining activities have started to cause damage to the river. From preliminary research conducted in Lodtunduh Village, Ubud District, Gianyar Regency shows that rocks taking start to show a very big change to the surrounding environment seen from the amount of material taken, the depth of excavation, the decrease of water calm, the noise and the decrease in river capacity. This condition brings consequences to some negative things such as the flow of the river that began to change as well as the area around the river that no longer pay attention to safety aspects as well as environmental aesthetics. The quality of declining river water gives a bad impact on the river and the threat of cliff areas around the river that have the potential of landslides. This study uses quantitative and qualitative 
descriptive methods with the expected results in the form of a comprehensive and innovative Tukad settlement policy so that river damage can be prevented. The end result of this research is the existence of a policy pattern in rock mining in the Oos watershed area, so that greater damage can be avoided.

Keywords: Oos river, rock mining, river damage

\section{PENDAHULUAN}

Tukad Oos merupakan salah satu sungai yang mengalir di sebelah barat kawasan wisata Ubud dengan sumber air berada di daerah Tampaksiring dan bermuara ke bagian selatan di pantai Sukawati. Sungai ini merupakan sumber utama pemenuhan kebutuhan air irigasi bagi beberapa Subak yang ada di wilayah Kabupaten Gianyar. Sungai ini juga menjadi salah satu areal utama penambangan batu padas yang memiliki kualitas terbaik di Bali dilihat dari warna, tekstur dan kekuatan bahan yang berlokasi di Desa Lodtunduh di sebelah barat Ubud.

Pada jaman dahulu pemakaian batu padas terbatas hanya untuk bangunan suci dan perumahan bangsawan/keraton di Bali maka saat ini sejalan dengan perkembangan jaman dan kepariwisataan pemakaian batu padas semakin banyak dimanfaatkan sebagai material ragam hias di berbagai bangunan seperti kantor, sekolah serta di sektor kepariwisataan seperti hotel, villa, museum, restoran dan yang lainnya. Melihat fenomena ini bisa dipastikan permintaan terhadap material batu padas menjadi semakin meningkat dari waktu ke waktu. Permasalahan yang muncul sekarang ini adalah permintaan terhadap batu padas tidak seimbang dengan persediaan batu padas yang ada di sekitar tebing sungai yang cenderung tetap bahkan mulai berkurang.

Pengambilan batu padas di Tukad Oos di Desa Lodtunduh secara berlebihan berdampak buruk pada sungai tersebut karena memberi efek rusaknya tebing sungai, menurunnya kapasitas sungai, memicu terjadinya longsor, menurunnya kualitas air dan udara, menigkatnya kebisingan serta meningkatnya sedimen yang terhanyut di badan sungai. Melihat kondisi ini ini sangat diperlukan suatu analisis teknis yang strategis dan inovatif sehingga penambangan batu padas yang dilakukan tidak berpotensi merusak kelestarian Tukad Oos .

Berdasarkan dari permasalahan yang ada di wilayah Tukad Oos dapat disampaikan beberapa permasalahan sebagai berikut :

a. Bagaimanakah kondisi penambangan batu padas di Tukad Oos saat ini?

b. Bagaimanakah kategori kerusakan Tukad Oos saat ini?

c. Bagaimanakah konsep konservasi yang perlu dilakukan mengatasi permasalahan yang ada sehingga kelestarian sungai bisa tetap terjaga dalam mendukung konsep pelestarian pariwisata budaya di daerah Ubud dan sekitarnya.

Sementara tujuan dari penelitian ini adalah untuk menjawab permasalahan yang ada yaitu :

a. Memetakan kondisi penambangan batu padas di Tukad Oos saat ini

b. Menentukan kategori kerusakan Tukad Oos

c. Menentukan konsep konservasi yang tepat sesuai dengan karakteristik Tukad Oos 


\section{METODE PENELITIAN}

Pelaksanaan penelitian secara garis besar dilaksanakan dalam bentuk pengumpulan informasi (pengumpulan data sekunder dan primer), survei lapangan, analisis permasalahan, serta perumusan pola konservasi sungai.

a. Survei Kondisi Sungai dan Penambangan

Melakukan survei lapangan untuk mengetahui kondisi sungai saat ini, meliputi antara lain: Pengumpulan data daerah penambangan, Pengumpulan kegiatan fisik pengelolaan sungai, pengumpulan data pada Kantor Dinas PU Kabupaten Gianyar dan Balai wilayah Sungai Bali Penida terkait dengan studi yang pernah dilakukan dan rencana studi yang mungkin akan dilakukan,melakukan wawancara dengan masyarakat sekitar sungai terkait dengan harapan dan keinginan masyarakat terhadap usaha pengelolaan dan perbaikan Tukad Oos.

b. Inventarisasi

Inventarisasi merupakan pengumpulan data terkait dengan kondisi yang ada saat ini meliputi sistem aktifitas tambang, kondisi sungai, partisipasi masyarakat serta peran Pemerintah

c. Analisis

Pekerjaan analisis yang dilakukan meliputi analisis sebagai suatu kesatuan. Adapun analisis yang dilakukan meliputi :

1. Analisis hidrologi untuk menentukan hujan rancangan dan banjir rancangan

2. Analisis hidrolika untuk menentukan besarnya kapasitas sungai dan kapasitas debit pada bangunan serta pengaruh penampang sungai terhadap kemungkinan terjadinya banjir

3. Analisis kegiatan penambangan

4. Analisis kerusakan sungai

5. Analisis Sosial ekonomi dan budaya masyarakat di sekitar areal penambangan

6. Kajian teknis pelestarian sungai

\subsection{Analisis Kerusakan Sungai}

Menurut Kementerian Pekerjaan Umum dan Perumahan Rakyat, 2015 penilaian kerusakan sungai akibat penambangan dinilai dari dua hal yaitu dari kondisi fisik sungai dan dari operasional penambangan. Aspek kondisi fisik sungai disebabkan oleh beberapa hal yaitu penyempitan alur, erosi dasar sungai, longsoran tebing baik kanan maupun kiri, kepadatan tanaman dalam bantaran, seimentasi di dasar sungai, garis sempadan serta kondisi aliran di bagian muara.

Dilihat dari operasional penambangan, penilaian kerusakan sungai ditinjau dari hambatan air, aktifitas penambangan sedimen pada alur sungai, aktifitas penambangan sedimen pada bantaran sungai, pemanfaatan daerah sempadan luar tanggul serta akibat dari buangan air limbah ). Indikator penilaian dibedakan atas tiga kategori yaitu kondisi baik (71-100\%), kondisi sedang (51-70) dan kondisi buruk (0-50\%).

Sementara menurut sistem penilaian kerusakan sungai yang dikeluarkan Oleh Fakultas Teknik Universitas Diponegoro, 2014 penilaian terhadap kerusakan sungai dilihat dari empat kategori yaitu teknik penambangan, kecepatan penambagan, kedalaman tebing galian serta tingkat erosi. Indek kerusakan sungai dibagi menjadi tiga kondisi yaitu rusak ringan $(0,00-1,5)$, rusak sedang $(1,6-3,5)$ dan rusak berat $(3,6-5)$ 


\subsection{Analisis Bahan Tambang}

Peraturan Pemerintah Nomer 27 Tahun 1980 menjelaskan secara rinci bahan-bahan galian dapat dibagi menjadi 3 kelompok besar ayitu gologan A, B dan C. (PP No, 27 tahun 1980), (ESDM Bali, 2014)

a. Golongan A adalah tambang yang berhubungan dengan situasi strategis keamanan negara seperti uranium

b. Golongn B adalah golongan tambang yang dikuasai oleh negara seperti minyak bumi

c. Golongan $\mathrm{C}$ adalah bahan tambang yang sebagian besar untuk keperluan bahan konstruksi seperti pasir,batu dan yang lainnya

\subsection{Penentuan Kelayakan Penambangan}

Untuk menentukan kelayakan penambangan suatu deposit bahan tambang, terlebih dahulu perlu dilakukan kajian yang mencakup berbagai aspek di sekitar serta mempertimbangkan peraturan perundang-undangan yang berlaku yang sifatnya lintas sektoral. Aspek-aspek yang perlu dikaji adalah:

a. Aspek penggunaan lahan di suatu lokasi deposit bahan tambang

b. Aspek geologi

\subsection{Pengelolaan Sungai berkelanjutan}

Pembangunan wilayah keairan khususnya sungai di dunia dewasa ini sebagian besar masih menggunakan pola pendekatan rekayasa teknik sipil hidro secara parsial sehingga hasil rekayasa ini sangat sangat terkesan lepas bahkan kadang bertentangan dengan kepentingan kelestarian ekologi atau lingkungan (Maryono, 2008, Kodoati, 2014). Pola rekayasa hidrolik murni diartikan bahwa dalam penyelesaian masalah di wilayah keairan khususnya sungai hanya didasarkan pada fungsi hidrolis semata, tanpa mempertimbangkan dampak negatif dan keterkaitannya terhadap komponen ekologis yang ada. Sebagai contoh fungsi suatu sungai menurut konsep hidrolik murni hanya dipandang sebagai suatu saluran hidrolik pembuangan kelebihan air menuju laut di bagian muara. Jadi dengan konsep ini semua sungai sebaiknya diluruskan dan di dinding/talud dengan harapan air cepat mengalir ke wilayah hilir.Dengan konsep ini ekologis sungai otomatis akan hancur total.

Konsep konservasi sungai berkelanjutan adalah pendekatan integral dalam pembangunan wilayah sungai yang memasukkan unsur dan pertimbangan hidrolika dan ekologi secara sinergis (Maryono, 2007). Konsep ini justru dapat mengahsilkan sinergis mutualisme mengahsilkan rekayasa yang menguntungkan baik hidrolik maupun ekologi lingkungan.

\subsection{Analisa Hidrologi}

Analisis Hujan Rancangan

Analisis hujan rancangan merupakan salah satu cara untuk menetapkan besaran hujan rancangan dengan kala ulang tertentu untuk data yang diperoleh dari rekaman data baik data hujan maupun debit yang didasarkan pada sifat statistik data yang tersedia untuk memperoleh probabilitas besaran hujan atau debit di masa yang akan datang (Aditya, 2014), (Arif, 2014), (Aryadi,2014) 
a. Metode Log Pearson Type III

Dalam metode Log Pearson Type III data-data ditransform ke harga logaritma kemudian dihitung parameter-parameter statistiknya. Soemarto, 1985 ), (Harto, 1993) :

b. Metoda Distribusi Gumbel

Metoda distribusi Gumbel banyak digunakan dalam Analisis frekuensi hujan, dengan rumus sbb: (Soemarto, 1989), (Harto, 1993)

\subsection{Analisis Banjir Rancangan}

Perhitungan banjir rancangan diperlukan untuk mengetahui besarnya debit yang terjadi pada suatu ruas sungai.

Rumus dari hidrograf satuan Nakayasu adalah (CD Soemarto, 1985) :

$$
\mathrm{Q}_{\mathrm{p}}=\frac{\mathrm{C} \cdot \mathrm{A} \cdot \mathrm{R}_{0}}{3,6 \cdot\left(0,3 \cdot \mathrm{T}_{\mathrm{p}}+\mathrm{T}_{0,3}\right)}
$$

\subsection{Analisis Kapasitas}

Analisis kapasitas merupakan analisis untuk mengetahui kapasitas tampungan alur sungai. Rumus yang dipakai adalah rumus Manning (Chow, 1987) sebagai berikut :

$\mathrm{Q}=\mathrm{AV}$

$$
\mathrm{V}=1 / \mathrm{n} \mathrm{R}^{2 / 3} \mathrm{~S}^{1 / 2}
$$

\section{HASIL DAN PEMBAHASAN}

\subsection{Kondisi Kabupaten Gianyar}

Kabupaten Gianyar terletak antara $08^{\circ} 18^{\prime} 52^{\text {“ }} \mathrm{LS}-08^{\circ} 37^{\prime} 50$ “ $\mathrm{LS}$ dan $115^{\circ} 05^{\text {، }}$ 29 “ BT $-115^{\circ} 22$ ' 23 “ BT. Berbatasan dengan Kabupaten Badung dan Kodya Denpasar di sebelah Barat, Kabupaten Bangli di sebelah Utara, di sebelah Timur berbatasan dengan Kabuaten Bangli dan Klungkung dan disebelah selatan berbatasan dengan selat Badung dan Samudra Indonesia. Luas wilayah Kabupaten Gianyar 36.800,00 Ha atau 6,62 \% dari luas Propinsi Bali. (BPS, Bali 2017)

a. Struktur Geologi dan Potensi Pertambangan

Wilayah Kabupaten Gianyar mempunyai formasi geologi yang seragam (menurut penelitian/penyelidikan yang ada, yaitu dari Peta Geologi yang diterbitkan oleh Direktorat Geologi Bandung tahun 1971) yang terdiri dari muntahan vulkanik Buyan Beratan dan Batur, berumur kwarter atas, yang komponen utamanya terdiri dari tufa dan endapan vulkanis. Sebagian dari batuan tufa tersebut terkompaksi sehingga terbentuk batu padas

\section{b. Kegiatan Penambangan di wilayah Sungai}

Kegiatan penambangan di wilayah sungai Kabupaten Gianyar sebgaian besar merupakan aktifitas tambang batu padas. Kegiatan penambangan dilakukan di beberapa sungai potensial yaitu sungai DAS Oos, sungai Petanu dan sungai Pakerisan 


\subsection{Kondisi Tukad Oos}

Tukad Oos mengalir di bagian barat Kabupaten Gianyar dengan hulu berada di sekitar Kabupaten Bangli dan bermuara ke pantai selatan di Sukawati. Secara umum alur sungai ini berkelok-kelok dengan kemiringan yang cukup bagus. Air dari sungai ini dimanfaatkan juga untuk irigasi di beberapa daerah irigasi dib awahnya seperti daerah irigasi Cengcengan dan daerah irigasi lainnya. Sungai ini memiliki corak daerah aliran

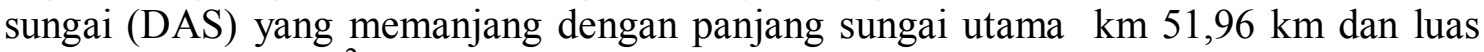
DAS $=119,95 \mathrm{Km}^{2}$. Kondisi Das secara umum masih bagus terlihat dari kondisi das dengan vegetasi yang masih bagus.

\subsection{Potensi Kerusakan Sungai Oos}

Potensi kerusakan sungai yang diakibatkan oleh kegiatan penambangan sangat bervariasi tergantung pada intensitas dan lokasi penambangan. Secara lebih terperinci dapat disebutkan kerusakan akibat potensi tambang adalah sebagai berikut : kerusakan Fasilitas Umum, rusaknya Alur Sungai, meningkatnya kekeruhan air sungai, rusaknya bentang alam, penurunan kualitas air, pemakaian mekanisasi

\subsection{Kendala Penataan Penambangan di Tukad Oos}

Kegiatan penambangan membawa dampak baik positif juga negatif terhadap lingkungan sosial budaya bagi masyarakat yang di sekitarnya juga bagi masyarakat Bali secara keseluruhan. Bali sebagai daerah pariwisata utama di Indonesia mengalami pembangunan fisik yang sangat signifikan sehingga sangat memerlukan berbagai material untuk pembangunan tersebut. Disamping itu juga pembangunan tempat suci bagi agama Hindu dan balai sosial masyarakat Bali memerlukan material batu padas yang di ambil sebgain besar dari sungai-sungai yang ada di Kabupaten Gianyar. Keberadaan bahan tambang tersebut semakin hari menunjukkan peningkatan yang semakin pesat seiring dengan tingkat kesejahteraan masyarakat serta selera masyarakat terhadap keunikan nilai suatu bangunan. Aktifitas tambnag yang ada di masyarakat terbukti mampu meningkatkan nilai ekonomi masyarakat sekitar atapun penduduk pendatang yang bekerja di tempat tersebut.

Kebutuhan bahan tambang yang tinggi tidak diimbangi dengan penegakan aturan pengambilan bahan tambang melaluiaturan yang jelas. Sehingga masih banyak terdapat pengusahaan tambang tanpa mengantongi ijin dari instansi terkait.

\subsection{Analisis Hidrologi}

Analisis hidrologi dilakukan untuk mengetahui besarnya hujan rancangan dan banjir rancangan yang terjadi pada alur sungai.. Dalam analisis hidrolgi ini terdiri dari tiga perhitungan yaitu analisis hujan rancangan, analisis banjir rancangan dan analisis kapasitas sungai.

\subsection{Analisis Hujan Rancangan}

Analisis hujan rancangan didahului dengan analisis curah hujan wilayah dai beberapa stasiun yang ada di sekitar daerah studi. Stasiun yang dipakai dalam studi ini adalah stasiun Tampaksiring dan stasiun Tegalalang. 
Tabel 1. Hasil Analisis Hujan Rancangan Metode Log Pearsom Type III

\begin{tabular}{|c|c|c|c|} 
No & $\begin{array}{c}\text { Periode } \\
\text { Ulang (T) } \\
(\text { tahun })\end{array}$ & $\begin{array}{c}\text { Harga } \\
\text { Ekstrapolasi } \\
(\mathrm{Xt}) \\
(\mathrm{mm})\end{array}$ \\
\hline \hline & & & \\
\hline 1 & 2 & $-0,1313$ & 97,96 \\
\hline 2 & 5 & 0,7953 & 124,26 \\
\hline 4 & 10 & 1,3473 & 143,16 \\
\hline 5 & 20 & 1,7806 & 160,00 \\
\hline 6 & 25 & 1,9972 & 169,15 \\
\hline 8 & 100 & 2,4596 & 212,60 \\
\hline 9 & 200 & 2,8883 & 236,34 \\
\hline & 1000 & 3,3007 & 296,88 \\
\hline
\end{tabular}

Sumber : hasil perhitungan

\subsection{Analisis Banjir Rancangan}

Analisis banjir rancangan adalah suatu analisis untuk mengetahui besarnya debit banjir yang terjadi pada suatu DAS dengan memperhitungan hujan rancangan serta parameter DAS lainnya seperti panjang sungaiutama dan luas DAS koefisien pengaliran.

Tabel 2. Rekapitulasi Perhitungan Banjir Rancangan

\begin{tabular}{|c|c|c|c|c|c|c|c|}
\hline$T$ & Q2 & Q5 & Q10 & Q20 & Q25 & Q50 & Q100 \\
\hline 0,00 & 0,00 & 0,00 & 0,00 & 0,00 & 0,00 & 0,00 & 0,00 \\
\hline 1,00 & 2,68 & 3,40 & 3,92 & 4,38 & 4,63 & 5,22 & 5,82 \\
\hline 2,00 & 14,86 & 18,84 & 21,71 & 24,26 & 25,65 & 28,88 & 32,24 \\
\hline 3,00 & 41,64 & 52,81 & 60,85 & 68,01 & 71,89 & 80,95 & 90,36 \\
\hline 4,00 & 87,05 & 110,42 & 127,22 & 142,18 & 150,31 & 169,25 & 188,93 \\
\hline 5,00 & 153,92 & 195,24 & 224,95 & 251,41 & 265,78 & 299,27 & 334,06 \\
\hline 6,00 & 190,35 & 241,44 & 278,18 & 310,90 & 328,67 & 370,08 & 413,11 \\
\hline 7,00 & 180,92 & 229,48 & 264,40 & 295,50 & 312,39 & 351,75 & 392,65 \\
\hline 8,00 & 158,33 & 200,83 & 231,38 & 258,60 & 273,38 & 307,83 & 343,62 \\
\hline 9,00 & 132,73 & 168,36 & 193,98 & 216,79 & 229,18 & 258,06 & 288,06 \\
\hline 10,00 & 111,27 & 141,14 & 162,61 & 181,74 & 192,13 & 216,34 & 241,49 \\
\hline 11,00 & 93,28 & 118,32 & 136,32 & 152,36 & 161,07 & 181,36 & 202,45 \\
\hline 12,00 & 78,20 & 99,19 & 114,28 & 127,73 & 135,03 & 152,04 & 169,72 \\
\hline 13,00 & 67,34 & 85,42 & 98,41 & 109,99 & 116,28 & 130,93 & 146,15 \\
\hline 14,00 & 59,13 & 75,00 & 86,41 & 96,57 & 102,09 & 114,96 & 128,32 \\
\hline 15,00 & 52,43 & 66,51 & 76,63 & 85,64 & 90,53 & 101,94 & 113,79 \\
\hline 16,00 & 46,62 & 59,13 & 68,13 & 76,14 & 80,49 & 90,63 & 101,17 \\
\hline 17,00 & 41,45 & 52,57 & 60,57 & 67,69 & 71,57 & 80,58 & 89,95 \\
\hline 18,00 & 36,85 & 46,74 & 53,85 & 60,19 & 63,63 & 71,64 & 79,97 \\
\hline 19,00 & 32,76 & 41,56 & 47,88 & 53,51 & 56,57 & 63,70 & 71,10 \\
\hline 20,00 & 29,13 & 36,95 & 42,57 & 47,58 & 50,30 & 56,63 & 63,22 \\
\hline 21,00 & 25,90 & 32,85 & 37,85 & 42,30 & 44,72 & 50,35 & 56,21 \\
\hline 22,00 & 23,02 & 29,21 & 33,65 & 37,61 & 39,76 & 44,77 & 49,97 \\
\hline 23,00 & 20,66 & 26,20 & 30,19 & 33,74 & 35,67 & 40,16 & 44,83 \\
\hline 24,00 & 18,78 & 23,82 & 27,44 & 30,67 & 32,42 & 36,51 & 40,75 \\
\hline
\end{tabular}

Sumber : hasil perhitungan 


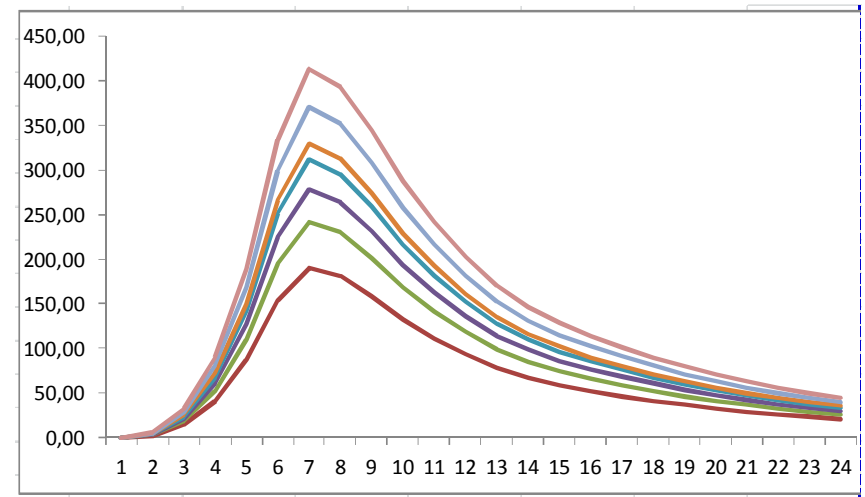

Gambar 1. Hidrograf Banjir Tukad Oos\

\subsection{Analisis Kapasitas sungai}

Analisis kapsitas sungai dilakukan untuk mengetahui kapasitas sungai berdasarkan hasil perhitungan debit banjir rancangan kala ulang 25 tahun (Q25). Dari analisis perbandingan dan data penampang sungai lokasi penambangan Desa Lodtunduh diperoleh hasil perhitungan sebagai berikut :

Q25 = 131,47 $\mathrm{m}^{3} / \mathrm{dt}$, lebar sungai $12 \mathrm{~m}$, tinggi tebing terendah $3 \mathrm{~m}$ dan kemiringan dasar sungai 0,02 diperoleh besarnmya debit banjir 25 tahun yangb isa dilewatkan oleh penampang sungai sebesar $163,65 \mathrm{~m}^{3} / \mathrm{dt}$. Dengan demikian jika kondisi sungai bersih dan tidak banyak tertimbun buangan sisa penambangan semestinya tidak terjadi banjir. Penyebab utamanya adalah lokasi penambangan yang berada di hulu sungai sehingga kemiringan sungai masih sangat miring sehingga kecepatan air menjadi lebih maksimal yang berakibat pada meningkatnya debit yang bisa dilewatkan.

\subsection{Penilaian Kinerja Sungai Terhadap Penambangan Batu Padas di Sungai}

Dari penilaian terhadap kinerja sungai akibat dari yang dilakukan diperoleh sebagai berikut seperti pada tabel berikut :

Tabel 3. Kerusakan Sungai Akibat Penambangan Dilihat dari Kondisi Fisik Sungai

\begin{tabular}{|c|c|c|c|}
\hline Parameter & Kondisi & Nilai (\%) & Keterangan \\
\hline \multirow[t]{3}{*}{ 1. Penyempitan } & Tidak ada & & \\
\hline & Ada, sedang & 55 & Terdapat penyempitan tampang sungai asli kurang dari setengahnya \\
\hline & Ada, besar & & \\
\hline \multirow[t]{3}{*}{ 2. Erosi Dasar } & Tidak ada & 85 & Ada perubahan perubahan kecil tidak mengganggu \\
\hline & Ada, sedang & & \\
\hline & Ada, besar & & \\
\hline \multirow[t]{3}{*}{ 3.Longsoran Tebing Kanan } & Tidak ada & & \\
\hline & Ada, sedang & 60 & Terdapat longsoran di tebing kanan kurang dari setengahnya panjang ruas \\
\hline & Ada, besar & & \\
\hline \multirow[t]{3}{*}{ 4.Longsoran Tebing Kiri } & Tidak ada & & \\
\hline & Ada, sedang & & \\
\hline & Ada, besar & 45 & Terdapat longsoran di tebing kiri lebih dari setengahnya panjang ruas \\
\hline \multirow[t]{3}{*}{ 5.Kepadatan tanaman dan Bantaran } & Tidak ada & 85 & Rumput dan tanaman kecil tidak mengganggu \\
\hline & Ada, sedang & & \\
\hline & Ada, besar & & \\
\hline \multirow[t]{3}{*}{ 6.Sedimentasi di dasar sungai } & Tidak ada & & \\
\hline & Ada, sedang & 70 & Terdapat gejala sedimentasi di belokan dalam sungai \\
\hline & Ada, besar & & \\
\hline \multirow[t]{3}{*}{ 7.Penetapan Garis Sempadan } & Ada & & \\
\hline & Dalam proses & & \\
\hline & Belum ada & 45 & Sudah ada peraturan garis sempadan tetapi blm bisa diterapkan \\
\hline \multirow[t]{4}{*}{ 8.Aliran Pada Muara Sungai } & Mengalir lancar & & \\
\hline & Mengalir terhambat & 65 & Muka air sungai antara muka air laut tinggi dan muka air laut rendah \\
\hline & Tidak mengalir & & \\
\hline & Rata-Rata & 63,75 & Rusak sedang \\
\hline
\end{tabular}


Tabel 4. Kerusakan Sungai Akibat Dilihat dari Operasional Penambangan

\begin{tabular}{|c|c|c|c|}
\hline Parameter & Kondisi & Nilai $(\%)$ & Keterangan \\
\hline \multirow[t]{3}{*}{ 1. Hambatan air } & Tidak ada & & \\
\hline & Ada,sedang & 60 & Terdapat benda yang berada di alur yang berakibat berkurangnya tampang sungai kurang dari setengahnya \\
\hline & Ada, besar & & \\
\hline 2. Aktifitas Penambangan sedimen & Tidak ada & 100 & Tidak ada aktifitas \\
\hline \multirow{2}{*}{ pada alur sungai } & Ada,sedang & & \\
\hline & Ada, besar & & \\
\hline 3. Aktifitas penambangan sediman & Tidak ada & & \\
\hline \multirow[t]{2}{*}{ Pada bantaran } & Ada,sedang & & \\
\hline & Ada, besar & 45 & Kegiatan penambangan telah menimbulkan kerusakan \\
\hline 4. Pemanfaatan Daerah Sempadan & Tidak ada & & \\
\hline \multirow[t]{2}{*}{ Luar tanggul } & Ada,terkendali & & \\
\hline & Ada, dan tidak terkend & 45 & Pemanfaaatamn sempadan tidak sesua peruntukan \\
\hline \multirow[t]{4}{*}{ 5. Buangan air limbah } & Tidak ada & & \\
\hline & Ada,terkendali & & \\
\hline & Tidak mengalir & 50 & Ada pembuangan limbah ke dalam yang sudah menimbulkan gangguan kualitas air \\
\hline & Rata-rata & 60 & Rusak sedang \\
\hline
\end{tabular}

Sumber : hasil analisis

Tabel 5. Kerusakan Sungai Berdasarkan Siatem UNDIP

\begin{tabular}{|c|c|c|c|}
\hline No. & Uraian & Nilai & Bobot Penilaian \\
\hline \multirow[t]{4}{*}{1} & Teknik Penambangan & & 0,5 \\
\hline & Benar & 1 & \\
\hline & Agak Benar & 2 & 1 \\
\hline & Salah & 3 & \\
\hline \multirow[t]{4}{*}{2} & Kecepatan Penambangan & & 0,5 \\
\hline & Lambat $\left(\leq 6 \mathrm{~m}^{3} /\right.$ hari $)$ & 1 & 0,5 \\
\hline & Agak Cepat $\left(7-8 \mathrm{~m}^{3} /\right.$ hari) & 2 & \\
\hline & Cepat $\left(>8 \mathrm{~m}^{3} /\right.$ hari) & 3 & \\
\hline \multirow[t]{4}{*}{3} & Kedalaman Tebing Galian & & 0,2 \\
\hline & $<20 \mathrm{~cm}$ & 1 & \\
\hline & $20-50 \mathrm{~cm}$ & 2 & \\
\hline & $>50 \mathrm{~cm}$ & 3 & 0,6 \\
\hline \multirow[t]{5}{*}{4} & Tingkat Erosi & & 0,5 \\
\hline & Kecil & 1 & \\
\hline & Sedang & 2 & 1 \\
\hline & Besar & 3 & \\
\hline & & Jumlah & 3,1 \\
\hline
\end{tabular}

Nilai Indek Kerusakan Sungai dikategorikan menjadi 3 bagian :
a. $\quad 0.00-1.5$ Rusak Ringan
b. $\quad 1.6-3.5$ Rusak Sedang
c. 3,6-5 Rusak Berat

\section{KESIMPULAN DAN SARAN}

\section{Kesimpulan}

Berdasarkan hasil observasi lapangan dan analisis yang telah dilakukan dapat disimpulkan beberapa hal yaitu :

1. Penambangan yang dialukan di Tukad Oos saat ini adalah penambangan batu padas yang areal penambangannya dilakukan disekitar tebing sungai dan daerah bantaran sungai. Penambangan telah menggunakan mesin yaitu mesin pemotong batu padas dan pompa dengan kedalaman penambangan mencapai $50 \mathrm{~m}$. Berdasarkan analisis kapasitas di titik penambangan di Desa Lodtunduh menunjukkan bahwa kapasitas sungai yang ada saat ini sebesar $163,65 \mathrm{~m}^{3} / \mathrm{dt}$ lebih besar dari debit banjir Q25 sebesar $131,47 \mathrm{~m}^{3} / \mathrm{dt}$ (tabel 2, gambar 1 ). Ini artinya penampang sungai yang ada masih mampu melewatkan debit banjir yang terjadi. 
Hal ini disebabkan oleh kemiringan sungai yang masih bagus serta dinding sungai yang masih tinggi (diatas $3 \mathrm{~m}$ )

2. Penilaian kerusakan sungai akibat penambangan dilihat dari 3 kondisi yaitu :

a. Kerusakan sungai dilihat dari kondisi fisik sungai terdiri dari aspek penyempitan alur sungai (nilai 55), erosi dasar (nilai 85), longsoran tebing kanan (nilai 60), longsoran tebing kiri (nilai 45), kepadatan tanaman dan bantaran (nilai 85), sedimentasi di dasar sungai (nilai 70), penetapan garis sempadan (nilai 45) dan aliran pada muara sungai (nilai 65). Berdasarkan kese;luruhan nilai yang ada maka rata-rata nilainya sebesar 61,75 atau dalam kondisi rusak sedang (tabel 3).

b. Kerusakan sungai dilihat dari operasional penambangan menunjukkan dari hasil analisis pengaruh hambatan air (nilai 60), aktifitas penambangan sedimen pada alur sungai (nilai 100), aktifitas penambangan pada bantaran sungai (nilai 45), pemanfaatan daerah sempadan luar tanggul (nilai 45) dan buangan air limbah (nilai 50). Berdasarkan nilai yang ada maka rata-rata nilai kerusakan sungai akibat penambangan nilainya sebesar 60 atau kategori kerusakan sungai sedang (tabel 4).

c. Penilaian kerusakan sungai berdasarkan sistem yang dikeluarkan oleh fakultas Teknik UNDIP menunjukkan indek kerusakan sungai sebagai berikut : teknik penambangan (indek 1), kecepatan penambangan indek $(0,5)$, kedalaman tebing galian (indek 0,6) dan tingkat erosi (indek 1). Nilai rata-rata indek menunjukkan nilai 3,1 yang artinya penambangan menimbulkan kerusakan sungai Oos pada taraf rusak sedang (tabel 5).

Konsep konservasi yang bisa direkomendasikan dalam hal pengamanan sungai Oos akibat dari penambangan batu padas adalah penegakan aturan sempadan sungai secara lebih tegas, pembatasan kedalam galian, pengetatan ijin pertambangan dan yang terakhir perlu langkah inovatif dalam industri jasa konstruksi untuk mulai memikirkan material pengganti batu padas alami dengan batu padas buatan sehingga pengambilan batu padas yang ada di alam bisa di kurangi..

\section{Saran}

Pemakaian batu padas yang semakin banyak perlu diimbangi dengan penyediaan yang seimbang. Jika persediaan di alam semakin menipis maka langkah inovatif dalam dunia industri konstruksi perlu dilakukan dengan melakukan terobosan pembuatan batu padas buatan berbahan material yang lebih mudah bisa diadakan tanpa merusak alam.

\section{DAFTAR PUSTAKA}

[1] Badan EDSM Provinsi Bali (2014) Laporan Evaluasi Bahan Tambang Provinsi Bali, Denpasar, Dinas Pekerjaan Umum.

[2] Agus Maryono (2003) Pembangunan Sungai Dampak Dan Restorasi Sungai, Yogyakarta, Universitas Gajah Mada Press.

[3] Balai Penelitian dan Pengembangan Pengairan (2000) Standar Nasional Indonesia Perhitungan Banjir Rancangan, Jakarta, Departemen Pekerjaan Umum, Bidang Sumber Daya Air.

[4] Badan Pusat Statistik Kabupaten Gianyar (2017) Gianyar Dalam Angka 2017, Gianyar, Pemerintah Kabupaten Gianyar

[5] CD. Sumarto (1985) Hidrologi Teknik, Surabaya, Usaha Nasional 
[6] Kodoatie, Robert dan Sjarief, Rustam (2005) Pengelolaan Sumber Daya Air Terpadu, Yogyakarta, Andi

[7] Linsley, R.K dan Franzini, Josep B (1995) Teknik Sumber Daya Air, Jakarta, Erlangga

[8] Sharin (1990) Statistical Of Hidrology, Mc.Graw Hill

[9] Sri Harto (1993) Analisa Hidrologi, Jakarta, PT. Gramedia Pustaka Utama

[10] Suwarno (1991) Hidrologi : Pengukuran Dan Pengolahan Data Aliran Sungai., Bandung, Nova

[11] Suyono Sosrodarsono dkk. (1993) Hidrologi Untuk Pengairan, Jakarta, Pradnya Paramita

[12] Suyono Sosrodarsono dkk. (1985) Perbaikan dan Pengaturan Sungai, Jakarta, Pradnya Paramita

[13] Ven Te Chow (1987) Hidrolika Saluran Terbuka, Jakarta, Erlangga 